\title{
Political Narrative Fiction and the Responsibility of the Author
}

\author{
Tahereh Rezaei ${ }^{1, a^{*}}$, Mohsen Hanif ${ }^{2, b}$ \\ ${ }^{1}$ Allameh Tabataba'i University, Tehran, Iran \\ ${ }^{2}$ Kharazmi University, Tehran, Iran \\ a t.rezaei@khu.ac.ir, ${ }^{\mathrm{b}}$ mhanif@ut.ac.ir
}

Keywords: political narrative fiction, committed art, democracy, freedom. Political novelists

\begin{abstract}
Art in general and fiction in particular have had close affinities with politics throughout history. When there is a close tie between a narrative fiction and political issues then critics may deem it as "committed fiction". Political fiction is at the crossroads of political science and the art of fiction. And more often than not, novelists are involved with politics but not all of them are dubbed as or even consider themselves to be political novelists. In this article I attempt to investigate political fiction as a distinct genre produced (un)consciously by a range of (politically committed) novelists and critics. The authors discussed in this paper demonstrate dissimilar perspectives on freedom and democracy. Also, regarding political fiction and the responsibility of author, we will see how divergent is the attitudes of critics such as George Orwell, Allen RobbeGrillet, Juan Goytisolo, Mario Vargas Llosa and Isabel Allende.
\end{abstract}

\section{Introduction}

Shlomith Rimmon-Kenan defines narrative fiction as "the narration of a succession of fictional incidents" which is distinguished from narratives in other media, such as "film, dance, or pantomime" and which does not include nonfictional verbal narratives, like "gossip, legal testimony, news reports, history books, autobiography, personal letters, etc." [1]. Simply speaking, Fiction is a narrative in which creation prioritizes reality. On the other hand, Robertson defines "political science" as "the study of the nature, distribution and dynamics of power, usually at the national or international level, but sometimes at a very "micro' level" [2]. Indeed, Politics is the science of systematized power that explains who the winners are, and how and why they win.

Political fiction is at the crossroads of political science and the art of fiction. And more often than not, novelists are involved with politics but not all of them are dubbed as political writers. In this article I attempt to investigate political fiction as a distinct genre produced by committed novelists although some critics such as Stephen Pacheco are generally against the subject categorization of fiction and believe that it is impossible to draw a distinct line between various subject genres in a fiction [3]. From Pacheco's perspective, any fiction may deal with a range of subjects. And, therefore, for a critic like him hardly such a genre as War Fiction, Love stories or Political Novels do exist. Since novels usually have more than one theme or plot, it is difficult for critics to decide on whether the novel should be considered political or not. Le Rouge et Le Noire by Stendhal, David Copperfield by Charles Dickens and the Iranian epic length novel, Kaleydar, by Mahmoud Dolat-Abadi are among such works. In general, these critics believe that it is impossible to restrict the hidden layers of a work of fiction to a specific subject, and authors are unable to frame their art unless they aim to produce pure propaganda.

It is true that all narrative fictions might be analyzed from a variety of perspectives yet one should attend to what Boyers calls "book's sense of itself" [4] when classifying them in various subject genres. Although there are competing narratives in a piece of fiction which enables the critics to analyze it from psychological, ethical, or religious perspectives, "if the work is in fact properly designated a political novel, the determinate goal toward which the various elements tend will have something to do with ideas about community, collective action, and the distribution of power" [4]. From this vantage point, the main theme of political novels involves the political relations between the differing ruling states or the states and nations. Debates over ruling states, 
political and military opposition groups, party competitions, etc, fall under this heading. George Orwell's Animal Farm is a classical example, which fits in this genre. Therefore, critical modes of reading texts, such as contrapuntal interpretation, which seek to politicize every single text, are far from my concern in this article.

Art in general and fiction in particular have had close affinities with politics throughout history. When there is a close tie between a narrative fiction and political issues then critics may deem it as "committed fiction". Given that, three types of committed arts can be distinguished: committed art "inspired by politics", committed art "in the service of politics" and committed art "by mistake" [5]. Public Opinion associates committed art "in service of politics" with "totalitarian regimes". The communist party in the Soviet Union and Hitler's Nazi Party fully funded and monitored the art in their countries. The Nazi ordered to burn books by Zola, Freud, Einstein etc [6]. However, it is most often difficult to pinpoint whether a piece of art belongs solely to either of the categories cited above. Sholokhov, who was an ardent Leninist, and won the Lenin prize in 1960 for And Quiet Flows the Don was a committed artist. Nevertheless, what are the valid criteria to determine if he is a committed artist "inspired by politics" or is "in the service" of it.

This viewpoint has fueled heated debates among literary theoreticians. On the one hand, a critic such as Stuart Robins bitterly attacks authors who produce committed art in return for money and maintains that their work "is not fiction, nor literature, nor writing worthy of attention. It is polemic. It is marketing. It is disingenuous." He even is "willing to call it prostitution". On the other hand, some other critics, such as Rey Faraday Nelson stoically assert that he reads stories as stories and he "would read them - if he read them - just like any other works" [3]. The commitment of the author acquires certain significance that may differ in other socio-temporal situations.

\section{Discussion}

Some postmodernists celebrate the diluteness and open-endedness of the text. They detach themselves from the candor and directness of realists and late modernists and look down on how they tried to convey the theme of their texts. For instance, Roland Barthes writes, "It is impossible to represent the political: it resists all copying, even when you turn yourself out to give it all the more verisimilitude. Contrary to the inveterate belief of all socialist arts, where politics begins is where imitation ceases" [7]. In addition, Allen Robbe-Grillet criticizes the politicization of literature, and claims:

Writers are not necessarily political brains. And it's no doubt normal for most of them to limit themselves, in this field, to short, vague thoughts. But why do they feel such a need to express them in public at every opportunity? ... I believe, simply, that they're ashamed of being writers and live in perpetual terror they'll be reproached with it, be asked why they write, what good they are, what their role in society is.... The writer suffers, like everyone, over the misfortune of his fellow human beings; it's dishonest to pretend he writes to allay it.... The writer can't know what end he's serving. Literature isn't a means he's to place at the service of some Cause. [8]

In response to this view, Juan Goytisolo, the Spanish novelist and essayist, defends political novel but at the same time justifies Grillet's view of novelist in Democratic societies:

In France, where freedom of thought and speech are a reality, and equality of political rights is no empty formula, the novelist's relation to the public is entirely different, for example, than the one existing in Spain and the Latin American countries. The reason is very simple. When the social and economic conflicts that constitute the dynamic evolutionary force of a country can be freely aired through the natural outlets for the expression of conflicting interests, the writer's social responsibility to the public is not the same as in those other nations where the interests and aspirations of different pressure groups find no legal outlet for expression. [8] 
Mario Vargas Llosa, the Peruvian novelist, in "Discovering a Method for Writing", while exposing the reader to his writing styles, points to his conflicts with the Communist Party. That they disagreed on the function of literature, Llosa recognized, had its roots in the Party's conception of literature as a means in the service of propaganda. However, Llosa did not believe in this idea, except in The Time of Hero where the reader may notice that Marxist precepts are evident and aesthetic values are overshadowed by political concerns. Llosa frequently turns to committed literature and elaborates on the distinction between political novel and writing for politics. He takes side with Sartre who maintained that literature is not absurd and not mere entertainment but serious and that the author can give voice to his society and transform life [9]. Llosa reiterates that novels should improve life, not merely recount it. He does not like to strictly attach himself to pure history. But he affirms that he has been loyal to "some essential facts". For instance, in The Feast of the Goat although he has been inspired by Rafael Trujillo, the Dominican dictator, the episodes are not certainly mirroring the tangible reality. The female protagonist of this novel, Urania Cabral, is the daughter of one of Trujillo's ministers and a victim of Trujillo's political and personal barbarity. Although Urania was an invented character, what happened to her happened to many Dominican women [10]. But Llosa believes that it is improper to talk about politics in literature and thrust in political manifestos into narrative fiction. This is doomed to failure. Politics can serve literature, Llosa says, but its opposite is impossible [9]. Isabel Allende holds that, "if you are a novelist living in America, you don't need and you are not supposed to let different political issues affect your creative art, but in Latin America, almost every writer of my generation writes about the manifestations of political and social incidents. However, every book has political contents as well, even if a literary piece is altogether metaphorical, but I don't have any idea about its positive or negative effects." [11]

Goytisolo, Llosa and Allende are unanimous that the conditions of the society determine the contingency of political novel. They suppose novelists living in "democratic" countries such as France and America are no more supposed to write on politics. Unlike them, George Orwell, openly backs the interference of political mentality in writing novels. In Animal Farm and 1984 he criticizes absolutist powers like the ruling system in the Soviet Union although his argument is certainly affected by the Cold War and socio-political clashes between the Western and Eastern Bloc. In his essays, he endeavors to enlighten the reader by describing the conditions of absolutist powers. In "The Prevention of Literature", originally written in 1948, Orwell criticizes the ruling systems in both the Soviet Union and England and their treatment and reaction of the literati in these countries. He remarks:

...What is really at issue is the right to report contemporary events truthfully, or as truthfully as is consistent with the ignorance, bias and self-deception from which every observer necessarily suffers. In saying this I may seem to be saying that straightforward reportage is the only branch of literature that matters: but I will try to show later that at every literary level, and probably in every one of the arts, the same issue arises in more or less subtilized forms. [...] The Catholic and the Communist are alike in assuming that an opponent cannot be both honest and intelligent. Each of them tacitly claims that the truth has already been revealed, and that the heretic, if he is not simply a fool, is secretly aware of the truth and merely resists it out of selfish motives. [...] Freedom of the intellect means the freedom to report what one has seen, heard, and felt, and not to be obliged to fabricate imaginary facts and feelings. [12]

Orwell pointedly attacks the enemies of honesty and freedom in England. He regards the giants of media, film industry, the oligarchy and the lack of enthusiasm among the intellectuals to seek freedom as the archenemies of freedom in England. Totalitarian regimes, he believes, purposefully downgrade the writers' status to that of an entertainer or hireling:

Whenever one attempts to defend intellectual liberty against the claims of totalitarianism, one meets with these arguments in one form or another. They are based on a complete misunderstanding of what literature is, and how one should perhaps say 
why it comes into being. They assume that a writer is either a mere entertainer or else a venal hack who can switch from one line of propaganda to another as easily as an organ grinder changing tunes. [...] There is no such thing as a genuinely non-political literature, and least of all in an age like our own, when fears, hatreds, and loyalties of a directly political kind are near to the surface of everyone's consciousness. [12]

Orwell points that the intellectuals and writers are indifferent to the restrictions imposed on the freedom of thought of other intellectuals in totalitarian regimes, "but the only thing which is of any value to the writer as such is his freedom of expression taken away from him" [12]. In totalitarian regimes, Orwell argues, writers tend to "self-censorship" [12]. They unconsciously dictate to themselves what is favorable and what is not. Finally, he iterates that one should not mistake literature with political manifestos, and regimes that plan to put literature at the service of politics will be losers. In fact, he believes that the aesthetic values of a piece of fiction precede its political tendencies. However, Orwell presumably does not practice what he preaches. Readers of his narrative fictions know him as a committed artist "inspired by politics".

Along with George Orwell, many other novelists, such as Jack London, Maxim Gorky, John Steinbeck, Erich Maria Remarque, Milan Kundera, Ernest Hemingway, and dozens of other writers have stressed upon literature as a context to convey their political messages and are considered as committed novelists "inspired by politics". Political novels were less likely to be published without facing any obstacles. Authorities in different countries have often censored this group of committed artists. However, unlike the general belief, censorship did not merely take place in "totalitarian regimes". Interestingly, Orwell's Animal Farm was banned in some parts of America in 1987 on the ground that the book contained the phrase; "mass will revolt" [13]. This book has many a time been targeted by American school councils, African dictators and even in Arab states because of "written or illustrated material that contradicts Islamic and Arab values - in this text, pictures of alcoholic drinks, pigs, and other 'indecent images." "[13].

The ban on narrative fiction on political grounds started in England since it began to flourish. Gulliver's Travels was banned when published in 1726 on the ground that it "denounced on all sides as wicked and obscene." [13]. Black Boy by Richard Wright was repeatedly removed from the school library shelves because it was deemed "unsuitable for high school students" or "on the grounds of obscenity and that it teaches blacks to hate whites" [13]. Born on the Fourth of July, which is less autobiographical than creative, was placed in closed shelves because a parent complained that it was "Un-American" [13]. Kurt Vonnegut's Cat's Cradle, which satirizes the indifference and banality of American politician and atomic scientist, was occasionally banned from 1972 onward in different American states and schools. John Steinbeck's The Grapes of Wrath has been considered among the "most frequently" challenged books in America. It has been controversial since its publication in 1939. On August 18, 1939, committee in charge ordered copies of the novel to be removed from 20 public libraries for reasons of "indecency, obscenity, abhorrence of the portrayal of women, and for "portray[ing] life in such a bestial way"" [13]. Some works such as The Jungle by Upton Sinclair shook the head of the States. When the book was published, Roosevelt asked Sinclair to come to Washington and give his own account of Packingtown. It forced the president to send inspectors in order to investigate the matter. On their return, the inspectors reported that there was "nothing but filth, disease, intolerable stenches and a worse than bestial disregard of elementary decency" [13].

The War in Vietnam raised many issues and many authors turned to debate the bleak aspects of this imperialist war. Norman Mailer wrote Why are We in Vietnam? using "allegory to argue that the American way of thinking is largely responsible for the prosecution of that war" [13]. But it was censored and was kept out of libraries more by "acts of omission than by commission [...] even though board members had not read it; they reacted mainly on the basis of reviews. Christopher B. Deran, the director of the library, explained, "It wasn't just the words. The whole book has no valid purpose. It is a bad novel" [13].

Sometimes novels although seemed thematically direct by their authors, critics have interpreted them otherwise. If such narrative fictions are interpreted as political novels then they 
must be called committed fiction "by mistake". Dead Souls by Nicolai Gogol is an instance of such works. Some presume that through slandering Napoleon, Gogol is criticizing the ruling feudal system and comparing two different examples of feudal rulers as good and bad ones in this work. These critics believe that Gogol is ridiculing villagers rather than the feudal system in particular. However, some others have taken the work as a Christian epic turned to a novel [14]. Famously, when Milan Kundera heard a critic calling his work, The Joke, a critique of Stalinism, he interrupted by saying, "spare me your Stalinism, The Joke is a love story." [15]. It seems that sometimes even though almost everybody senses thick traces of political message in a narrative fiction, yet the author disagrees, and dismisses the political reading of his text. The Joke, to most readers is a bitter satire on a cruel regime, which interferes with the most detailed issues of their citizens.

Although early mainstream critics demeaned Mark Twain's The Adventures of Huckleberry Finn, for its "street vernacular spoken by Jim and Huck", half a century later leftist Black critics slandered it for its racist undertones. Ralph Ellison regarded the book as racist since Twain had assumed the partnership between the adolescent Huck with adult male Jim as equal [16]. The authorities in different American states slandered Margaret Mitchell's Gone with the Wind. Some who supported the censorship of the book expressed concern about the "negative depiction of freed slaves" [16]. Although A Farewell to Arms was mildly censored in America for its lingual and sexual innuendo, it was vastly banned in Italy for its account of the Italian retreat from Caporetto during World War I [16]. In fact, the socio-temporal situation of a text decides whether a work is political or not. Farewell to Arms is both about war and about love; however, American and Italian critics found different layers of the text pointed at their society.

Sometimes religious clashes are at the roots of political conflicts. The Crusades are good examples of such wars, which were both religious and political. Dante's Divine Comedy and Chaucer's Canterbury Tales are early examples of fictional texts that are at the crossroad of politics and religion. Works like the Gadfly by Ethel Lilian Voynich are thematically political but its political critique was not separable from its comments on institutionalized religion. Although the author conspicuously has made more effort to give an aesthetic and tangible picture of the hero, Gadfly, the incidents are taking place in a heated political atmosphere. Gadfly who thought the church is his savior finally unmasks its pretensions. In the domain of narrative fiction, the controversy over religion began with Cervantes' Don Quixote. This work was from the beginning of its publication a best-seller. However, the Inquisition committee in Spain whose power superseded mere religious matters began to expurgate the text before its publication. Don Quixote was not an exception and some parts of it were deemed offensive by the council [17].

\section{Conclusion}

The German expatriate anti-fascist writer Lion Feuchtwanger recounted when, in May 11, 1942, he along with Bertolt Brecht and Erich Maria Remarque intended to commemorate the Nazi Book Burning incident, they realized that they are not so much free to meet each other. The Allies saw them as some useful "enemy aliens". They were yet foreign threats, and were not allowed to travel far from their homes, to speak to large gatherings and to stay out after 8 p.m. Ironically, he explained, "Perhaps on this night, as so often in the past, British pilots will drop leaflets over Germany quoting from my books and praising democracy" [18] Committed artists have come a long way from Feuchtwanger to Goytisolo, Llosa and Allende. However, they still have a long way to go. Still there are examples of fictional books being censored on various grounds.

On the other hand, barely can anyone categorize the commitment of the artists as "inspired by politics" or "in service of the politics". Orwell regards both the democracy - which is different from freedom - in England and socialism in the Soviet Union as totalitarian regimes. Both states seek in one way or another to persuade the world that they represent the better way of life. Avantgardes, among them many postmodernists, are manipulated by the "democratic states" to stand for liberation, albeit through complex and clandestine machinations [19]. Goytisolo deemed it unnecessary to write political novels in France and Allende finds America the land where freedom 
is fulfilled. Although the extent of dissatisfaction in these countries seems far less than what was lately noticed in the Middle East, they tend to totally exclude political turmoil since the 2005 in France or perhaps the conditions, which gave rise to the latest "Occupy Wall-street" incident. Is it not possible then to include authors such as Goytisolo, Llosa and Allende as political novelists whose commitment is surreptitiously in service of the propaganda for "democracy"?

\section{References}

[1] S. Rimmon-Kenan, Narrative fiction: Contemporary poetics, Routledge, London and New York, 2002.

[2] D. Robertson, Routledge dictionary of politics, (Third Edition), Routledge, London, 2002.

[3] M. Hanif, M. Hanif, An Exploration into War Fiction, Tehran, Iran, 2009.

[4] R. Boyers, Atrocity and amnesia: the political novel since 1945, Oxford University Press, New York, 1985.

[5] I.I. Papadopoulou, A. Veneti, Committed art and propaganda, in: 55th Annual PSA Conference, Leeds, 2005, pp. 1-16.

[6] W.L. Shirer, The rise and fall of the Third Reich: A history of the Nazi Germany, Simon and Schuster, 1990.

[7] R. Barthes, Roland Barthes by Roland Barthes, trans. R. Howard, University of California Press, Los Angeles, 1994.

[8] J. Goytisolo, Literature pursued by politics, Review of Contemporary Fiction. 19(3) (1999) 38-43.

[9] H. Johnson-Wright, Junary interview with Mario Vargas Llosa by Heidi Johnson-Wright, 2002. Available: http://januarymagazine.com/profiles/vargasllosa.html.

[10] M.V. Llosa, M.I. Lichtblau, Discovering a method for writing, A Writer's Reality, Houghton Mifflin Co., Boston, 1992, pp. 39-60.

[11] I. Allende, I did not find the paradise (Behesht ra Peyda Nakardam), Mohammad-Javad Ostadi, Shargh Newspaper N. 1000, Tehran, Iran, 2010, p. 9.

[12] G. Orwell, The prevention of literature, Collected Essays (Second Edition), Secker \& Warburg, Pennsylvania, 1968.

[13] N.J. Karolides, Literature suppressed on political grounds, Facts on File, New York, 2006.

[14] J. Bortnes, Religion, in: M.V. Jones, F. Miller, R. Feuer, The Cambridge Companion to the Classic Russian Novels, Cambridge University Press, 1998, pp. 104-129.

[15] F.L. Restuccia, M. Kundera, "Homo Homini Lupus:" Milan Kundera's "The Joke", Contemporary Literature. 31(3) (1990) 281-299.

[16] D.B. Sova, Literature suppressed on social grounds, Revised Edition, Facts on File, New York, 2006.

[17] M. Bald, Literature suppressed on religious grounds, Revised Edition, Infobase Publishing, 2006.

[18] L. Feuchtwanger, Some useful 'Enemy Aliens': but anniversary of Nazi Book Burning finds them bound by red tape, New York Times, 11 May 1942, p. 14.

[19] C. Levine, Provoking democracy: Why we need the arts, Blackwell Publishing, Oxford, 2007. 